\title{
Sufi Healing and the Translation of Metafunction in Al-Hikam Aphorisms
}

\author{
Muhammad Yunus Anis', Mangatur Nababan², Riyadi Santosa ${ }^{2}$, Mohammad Masrukhi ${ }^{3}$ \\ ${ }^{1}$ Linguistics Postgraduate Program, Universitas Sebelas Maret, Indonesia \\ ${ }^{2}$ English Department, Universitas Sebelas Maret, Indonesia \\ ${ }^{3}$ Arabic Literature Study Program, Universitas Gadjah Mada, Indonesia \\ Corresponding Author: yunus_678@staff.uns.ac.id
}

\begin{abstract}
Studies related to Sufi healing have focused on the theories used by Hakim abu-Abdullah Moinuddin al-Chishtiyya related to the power of unconditional love to work healing miracles. The aspects contained in his Book of Sufi Healing consequently become the starting point for the elaboration of the Al-Hikam aphorisms, the monumental work of Ibn Athaillah As-Sakandari. This study aimed to find common ground between Sufi healing and the $\mathrm{Al}$ Hikam aphorisms. To find this meeting point, descriptive analysis was carried out from linguistic and cultural perspectives using Functional Systemic Linguistic theory and Ricoeur's translation theory applied to Arabic (L1) and Bahasa Indonesia and English language text. The main qualitative data were collected from Arabic clauses in the Al-Hikam aphorisms, comprising 435 clauses with a thematic structure derived from $100 \mathrm{Al}$-Hikam aphorisms. Linguistic theory was used to examine the text in detail from both micro and macro perspectives, the former being used to examine the shift in form and meaning, and the latter to examine the ideology of translation in conveying Sufi healing in the Al-Hikam aphorisms (infinite hermeneutics in translation). The results showed that the clause structure in Arabic can be divided into three main patterns (SVCOMP/entity-oriented, VSCOMP/event-oriented, and SCOMP/verbless sentence structure). In terms of Ricoeur's infinite hermeneutics, the position of wager was viewed from the lexical meaning of the Al-Hikam aphorisms, while the transformation stage in the model can be applied to the study of Al-Hikam aphorisms as the basis for understanding Sufi healing.
\end{abstract}

Keywords: Al-Hikam aphorisms; Arabic-Bahasa Indonesia translation; metafunction; shifting translation; sufi healing

\section{INTRODUCTION}

Al-Hikam aphorisms have long been the main reference for Sufism or Islamic Mysticism. There are many ways of life in the Al-Hikam aphorisms related to Islamic traditions. Al-Hikam has special characteristics to convery the message, especially from the perspective of linguistics, rhetoric, and aesthetics. This research focuses on the study of Al-Hikam in relation to its translation and the notions of Sufi healing. Sufi healing can be defined as a therapy in the literature of Sufism. The main data in this research are Arabic clauses collected from the Al-Hikam aphorisms. In this study, Al-Hikam aphorisms are used because it is an important source for the study of Sufi healing. In this case, the clause has been selected and analyzed as a source of meaning. This is a fundamental and theoretical foundation. This study investigates how a clause in Systemic Functional Linguistic (SFL) theory is positioned as a "source of meaning." It focuses on the analysis of the meaning of Arabic clauses in terms of the unity of metafunctional meanings and the use of the use of translation techniques in developing the form and meaning of the resultant translation. The study is related to the metafunction which has been transformed 
into the substance of Sufi healing. This is in line with the model of recovery of (events with meaning (symbolic) (Aufhebung) which was developed by Paul Ricoeur. In this model, there are three stages, namely: (1) the wager, (2) the verification, and (3) the transformation (Kharmandar, 2015). The wager is the first stage analysis of how to understand Al-Hikam aphorisms in terms of language and translation. The verification is the step on how to analyze $\mathrm{Al}$-Hikam aphorism from a metafunctional perspective. In the last stage, transformation, it tries to find the relationship between Al-Hikam aphorisms and Sufi healing. Studies related to Al-Hikam aphorisms, using the Paul Ricoeur model to find the nature of Sufi healing, has not yet been used. This linguistic and cultural approach which applies Halliday's metafunctional model and Paul Ricoeur's infinite hermeneutics model offers great promise in researching Sufi texts.

The book of Al-Hikam aphorisms is a magnum opus produced by Sheikh Ibnu Athaillah As-Sakandariy. In the text, there are many terms of transcendental Sufism between the Sufi believer and Allah. Several studies on the Al-Hikam aphorisms which are frequently referenced are those by Damayanti (2014) (Damayanti, 2014), (Rahem, 2017), (Abdullah, 2018), (Aryati, 2017), (Sakhok et al., 2019). These studies however, do not apply a Systemic Functional Linguistics and infinite hermeneutics to analyze culture. Existing studies focus on how Islamic scholars (ulama, kyai) convey Al-Hikam aphorisms to listeners, for example Ulil Abshar Abdalla and K.H. Soleh Darat. This then is a research gap in examining Sufi healing in the Al-Hikam aphorisms

In the Al-Hikam aphorisms, we can find clauses in Arabic language which have been translated into the Indonesian language. A clause is a grammatical unit of a group of words that consists of at least a subject and a predicate, and has the potential to become a sentence (Kridalaksana, 2009, p. 124). In Arabic, the equivalents to the term "clause" are 'ibārah (عبارة), jumlah shughrā (جملة صغرى), or jumailah (جميلة) (R. M. Baalbaki, 1990, p. 91). In SFL theory, a sentence that contains more than one clause is called a complex clause, and if a single clause stands alone, then the clause is called a simple clause (Wiratno, 2018, p. 53). Based on SFL theory, a clause contains three dimensions of meaning, namely, textual meaning, interpersonal meaning, and ideational meaning. These three dimensions of meaning are called metafunctional meanings.

1. The dimension of textual meaning sees the clause as a tool to convey a message (clause as message) (Halliday, 2004, p. 64).

2. The dimension of interpersonal meaning views the clause as a tool to perform meaning exchange (clause as exchange) (Halliday, 2004, p. 106).

3. The dimension of ideational meaning sees clauses as a tool to represent experiences (clause as representation) (Halliday, 2004, p. 168).

In this paper, these three metafunctional meanings are used to analyze clauses in Arabic which have been translated into Bahasa Indonesia.Grammatically speaking, clauses in Arabic, in terms of their structure, are of two types: (1) nominal clause/jumlah ismiyyah (Arabic) (Subject + Verb + Complement - SVCOMP and (2) verbal clause/jumlahfi'liyyah $(\mathrm{V}+\mathrm{S}+\mathrm{COMP})($ verbal sentence - event-oriented messages in Arabic language). The study of the SVCOMP clause structure based on the study of textual functions; is done to provide "new information" related to the predicate of the subject entity which is assumed to have been known between the locutor and interlocutor. The SVCOMP structure in Arabic is called entity-oriented whilethe VSCOMP structure in the study of Arabic is called "event-oriented." This is because the initial position of the verb (read: event) becomes the main locus that is studied. The focus of the VSCOMP structure is who does what, what happens, and how it happens (Holes, 1995, p. 205).

This research collects qualitative data which have been analyzed using a descriptive method (describing the structure of language). The method in this research comprises the following three basic steps: (1) data collection, (2) data analysis, and (3) reporting the result of data analysis. The data collected throughout the Al-Hikam aphorisms were clauses which have been translated into Bahasa Indonesia by Pustaka (2016). The data in AlHikam aphorisms were classified into two basic patterns of Arabic clauses, SVO and VSO. After the data were classified, the clauses were then analyzed by "thematic structure" to find the given information (Theme)and the new information (Rheme) in the Al-Hikam aphorisms. The given information in Arabic language has special markers, such as the definite article. The analysis started from the character of the clause in Al-Hikam aphorisms based on the thematic structures (Theme and Rheme). The study of theme and rheme became one of the bases for finding the relationship between Al-Hikam aphorisms and Sufi healing.

To examine the position of Sufi healing in $\mathrm{Al}$ Hikam aphorism, the Infinite Hermeneutics model is used. This study uses qualitative data and a descriptive narrative model. (Miles \& Huberman, 1992, p. 10) The study formulates three concurrent flows of activity: (1) data reduction, (2) data display, and (3) drawing conclusions. Data reduction refers to the process of selecting, focusing, 
simplifying, abstracting, and transforming the data in written-field notes or transcriptions. In this case, the data reduction starts from the Arabic clauses' analysis based on the thematic structure. The data reduction in this research focused in the variant models of theme and rheme and the Sufi healing aspects between Arabic and Indonesian language translation.

Theme and rheme in Arabic language are elaborated comprehensively by (Abdul-Raof, 2007) who analyses thoroughly the pragmatic function of theme. Abdul-Raof also focuses on the interaction of subject, theme, and agent in Arabic language. However, an investigation is yet to be produced on the theme and rheme from a translation perspective. Thus, this study can fill this research gap especially on theme and rheme in Arabic language from a translation perspective. Ali Almanna (2016, pp. 140-141) does however, elaborates on theme and rheme in Arabic language based on the translation perspective but it is from Arabic to English. by adding comments or annotations. Almanna also compares comprehensively "thematic progression" between Arabic and English. In this case, Almanna (2016, p. 141) emphasizes that the thematic progression pattern can be elaborated from the various kinds of themes: (1) topical theme, (2) textual theme, and (3) interpersonal theme. Research on theme and rheme construction still emphasizes the study of forms, types, and functions which are limited to linguistic studies (Dewi et al., 2020), (Wahyu et al., 2019), (Stella \& Gunawan, 2017), (Nugraha, 2017), (Potter, 2016), (Sujono et al., 2016), (Rini, 2015), (Sukesti, 2011), (Suparno, 1993). In addition, most of them do not provide the basic knowledge needed for an in-depth exploration of Sufi healing.

Meanwhile, research on the Al-Hikam aphorisms itself still emphasizes the study of Sufism, Islamic moral values, and the explanation process (syarah) of Al-Hikam aphorisms. Anis (2018) elaborates the ideology of translation in Al-Hikam aphorisms, but in this study, he has not examined the implementation of translation techniques. Previous researchers have conducted studies that specifically discuss the translation of theme and rheme include (Aini et al., 2020), (Ethelb, 2019), (Karini, 2016), (Wang, 2014), (Kadhim \& Al-shaibani, 2013). In this study the scope is limited to one type of translation theme. In this study, the analysis of the translation of theme and rheme seeks to find common ground between Al-Hikam aphorisms and Sufi healing. This differs from (Baker, 2018) who discusses theme and rheme from the translation perspective only. Baker uses the term markedness comprising two types: (1) marked theme (unusual or atypical) and (2) unmarked theme (most usual or typical). A marked theme consists of three types: (1) fronted theme (atypical to occur initially); (2) predicated theme (it-structure) and; (3) identifying theme (Whstructure). Based on this review of previous studies, it can be concluded that studies related to the translation of the theme and rheme in the Al-Hikam aphorism is a research gap.To date there is no study which specifically discusses: (1) Sufi healing in terms of Al-Hikam aphorism, (2) Sufi healing in Al-Hikam aphorisms using the metafunction model, (3) Sufi healing in Al-Hikam aphorisms using Paul Ricoeur's analysis model related to infinite hermeneutics, (4) thematic structure (theme + rheme) in Al-Hikam aphorism as the basis for the analysis of Sufi healing studies.

The research questions to be addressed in this study are: (1) how do the metafunctional meanings in the Al-Hikam aphorisms serve as the basis for Sufi healing? (2) how is the micro-analysis of the translated aphorisms related to the metafunctional model?, and (3) how is the macro analysis in the translation product of Al-Hikam aphorism related to the infinite hermeneutics model?

\section{FINDINGS AND DISCUSSION}

This section covers a discussion of Al-Hikam aphorism translations in terms of its metafunctional meanings: (1) clause as message, (2) clause as exchange, and (3) clause as representation. The analysis also focuses on translation techniques and translation shifts in each discussion of the metafunctional meanings. At this level, analysis of Al-Hikam aphorisms is investigated based on NahwulQulub written by (Al-qusyairi, 2005). At the same time, studies related to the relationship between Al-Hikam aphorisms and Sufi healing is specifically discussed using the infinite hermeneutics model, they are: 1) the wager, (2) the verification, and (3) the transformation (Kharmandar, 2015).

\section{Clause as Message in Al-Hikam Aphorisms}

In this dimension, clauses are positioned textually as sources of meaning used to organize messages or information. In this dimension, a clause is investigated as having an order of distribution of information. Information considered more important usually takes precedence by placing it at the front of the clause, while the part that is suggested is the part that complements the information previously conveyed. The more important part is called the theme, and the suggested part is called the rheme. Studies related to the starting point of an utterance have a very important position in the study of Sufi healing. For example, how do we know if the 
following sentence (ilāhiy... anāl-faqīru fì ghinā ... fakaifa là akūnu faqīran fì faqriy (As-Sakandariy, 2008, p. 109)) is a prayer? This can be determined because the utterance begins with the phrase /ilaahiy/ "oh My God." Therefore, knowing the starting point in an utterance is important in the study of Sufi healing, because the readers can find out what is emphasized - by what comes first. One of the studies discussing the structure of information is the textual metafunction to determine the position of theme and rheme.

Theme and rheme construction in Arabic language is found in the structure of SVCOMP (entity-oriented), VSCOMP (event-oriented), and SCOMP (verbless sentence). An example of the study of clauses as a message is found in the following Al-Hikam aphorism.

$$
\text { شعاعُ البصيرة يشهدك قربه منك }
$$

Syu 'ā'ul-bashīrah yusyhiduka qurbahu minka Sinar mata hati membuatmu menyaksikan kedekatan-Nya denganmu (Pustaka, 2016, p. 68). The eyes of the heart make you witness His closeness to you

Table 1. Theme, Rheme and SVCOMP

\begin{tabular}{|l|l|l|l|}
\hline & S & V & COMP \\
\hline A* $^{*}$ & Syu'a' 'ul-bashīrah & yusyhiduka & qurbahu minka \\
\hline & & & \\
\hline BI*. $^{*}$ & Sinar mata hati & $\begin{array}{l}\text { membuatmu } \\
\text { menyaksikan }\end{array}$ & $\begin{array}{l}\text { kedekatan-Nya } \\
\text { denganmu }\end{array}$ \\
\hline & THEME & RHEME & \\
\hline
\end{tabular}

* Key: A=Arabic, BI=Bahasa Indonesia

Table 1 shows that the phrase /syu' $\bar{a}$ 'ul-bashìrah/ "light of the heart's eyes" occupies the initial position of a clause. This phrase becomes the starting point of a clause, so that the phrase is in the position of the clause's theme. Thus, the data in Table 1 describes an entity from the heart's eye (Syu 'á'ul-bashirah), assuming that the writer and the reader already understand what is meant by the light of the heart's eyes. So, what is the new information from the light of the heart's eyes? The light of the eyes of the heart will make you (human) witness the closeness of Allah SWT with you (human). This new information is the rheme. From Table 1 above, it can also be concluded that in the Arabic SVCOMP structure, the theme construction is occupied by the subject. Meanwhile, the rheme construction contains verbs and complements $(\mathrm{V}+$ Comp). The following data is the VSCOMP structure in Arabic. The data can be linked to the book Nahwul Qulub, written by Imam Qusyairiy. Nahwul Qulub is a way to say praiseworthy words based on the heart and is a dialogue between man and God. There have been a number of scholarly studies related to Sufi healing and Nahwul Qulub such as: (Al-Chishtiyya, 1991) and (Syukur, 2011). The Book of Sufi Healing is used here to elaborate the aphorism of Al-Hikam, such as: (1) health, (2) the hierarchy of creation, (3) the stations of the soul, (4) food and health, (5) the Four Essences of the body (Akhlāt), (6) foods of the prophet, (7) herbal formulas for common ailment, (8) fasting: the best medicine, (9) The Postures of the Prophet (Salät), praying to God, and (10) the Universe of the Breath.

From the analysis in Table 1, it can be seen that the position of syua'ul bashirah is in the position of the theme. The Sufi healing offered in the textual meaning is found in the words which appear first in an Al-Hikam aphorism. In this case, the words which appear first is the form mubtada (the primate). The book Nahwul Qulub explains that mubtada 'is free from amil zahir (Active Element - Apparent, in Arabic Language) (Al-qusyairi, 2005). There are two kinds of active elements in Arabic language (1) oral (amil lafdziy - amil zahir), it appears in pronunciation and writing, and is represented by letters, verbs and nouns having an influence over various other words, and (2) moral (āmil ma'nawiy), it is perceived by the mind not by senses (El-Dahdah, 1993).

From this data (table 1), we can conclude that to achieve the goal of worship, our hearts must be clean (free), without any temptation from amil zahir. On the other hand, based on Table 1, we can conclude that the phrase Syu 'a 'ul-bashirrah using the idhafah construction. Idhäfah (annexation) is a relation between two nouns in Arabic language; the first noun is called annexing (al-mudhāf) and the second annexed (al-mudhāf ilaih), both forming one single word (El-Dahdah, 1993, p. 73). When an ism (noun) is included in the form of idhafah, then the ism will have a weak vowel (adh'af harakat). Before entering into the idhafah construction (annexation in Arabic), the ism (noun) is in a strong form, and has a strong vowel (aqwa harakat). For example, in the sentence "a servant of God must empty his heart to be strong," there is no need to lean on anything (idhafah is leaning on anything). In this case the word /bashirah/ is laid in the weak vowel (adh 'af harakat), because it relies on other words (syu'ā'ul).

A sentence in Arabic can not only start with a noun (ism) butalso with a verb as in the following sentence:

$$
\text { تنو عتُ أجناسُ الأعمال لتتوع واردات الأحوالٍ }
$$


Tanawa'at ajnāsul-a'māl litanawu'i wāridātilahwāli

Jenis amal itu bermacam-macam karena asupan hati juga beragam (Pustaka, 2016, p. 18)

There are many types of good deeds because what is in the heart is also manifold.

Table 2. Theme, Rheme and VSComp

\begin{tabular}{|c|c|c|c|}
\hline & $\mathbf{V}$ & $\mathbf{S}$ & СОМР \\
\hline Arab & Tanawa'at & ajnāsul-a'māl & $\begin{array}{l}\text { litanawu'i } \\
\text { wāridātil-ahwāali }\end{array}$ \\
\hline Ind. & $\begin{array}{l}\text { bermacam- } \\
\text { macam }\end{array}$ & jenis amal itu & $\begin{array}{l}\text { karena asupan } \\
\text { hati juga beragam }\end{array}$ \\
\hline & THEME & \multicolumn{2}{|l|}{ RHEME } \\
\hline
\end{tabular}

From Table 2 above, it can be seen that the theme and rheme are positioned in the VSCOMP structure in Arabic. The theme position is occupied by the verb tanawa 'at (تنوعتُ). Lexically, the verb ta-na-wa means to be or become diverse, varying, and varied (R. Baalbaki, 2009 , p. 382). The clause above focuses on events given the use of a verb $(t a-n a-w a)$ The linguistic units after the verb, namely subject and complement occupy the rheme position. Apart from the SVCOMP and VSCOMP structures, in Arabic, we also find the SCOMP structure which is often described as verbless. From the data above, we can see that the position of the theme is occupied by the verb. In Sufi literature, Nahwul Qulub explains that fi'l madhi is $f^{\prime} l$ (verb) which always focuses on the past (Al-qusyairi, 2005). The verb ( $\left.f^{\prime} l\right)$ does not immediately move to pursue the future, in essence this is a symbolic play. Because of that, this type of $f^{\prime} l$ is categorized by the Sufis as a weak verb, so that fil madhi is marked by fatkhah (vowel "a" in Arabic) at the end of the verb. Fatkhah is the representation of a light sound. Besides the SVO) and VSO-patterned sentences in Arabic there is also the $\mathrm{S}+\mathrm{COMP}$ pattern as in the following sentence:

$$
\text { الحزنُ على فقدان الطاعة مع عدم النهوض اليها من علامات الإغتر ار }
$$

Al-huznu 'alā fuqdānith-thā' 'ati ma'a 'adaminnuhūdh ilaihā min 'alamātil-ightirārr

Sedih karena kehilangan kesempatan berbuat ketaatan, namun tanpa disertai upaya untuk bangkit mengerjakannya, merupakan salah satu tanda ketertipuan (Pustaka, 2016, p. 129).

Sad because of losing a chance to be obedient, but without an effort to arise to do it, is one of the signs of being deceived.

Table 3. Theme and Rheme in SCOMP

\begin{tabular}{|c|c|c|}
\hline & $\mathbf{S}$ & СОМР \\
\hline A & $\begin{array}{l}\text { Al-huznu 'alā fuqdānith-thā'ati } \\
\text { ma'a 'adamin-nuhūdh ilaihā }\end{array}$ & $\begin{array}{l}\text { min 'alamātil- } \\
\text { ightirār }\end{array}$ \\
\hline BI. & $\begin{array}{l}\text { Sedih karena kehilangan } \\
\text { kesempatan berbuat ketaatan, } \\
\text { namun tanpa disertai upaya } \\
\text { untuk bangkit mengerjakannya }\end{array}$ & $\begin{array}{l}\text { merupakan } \\
\text { salah satu tanda } \\
\text { ketertipuan }\end{array}$ \\
\hline & THEME & RHEME \\
\hline
\end{tabular}

From Table 3 above, it can be seen that the position of the theme is filled by the subject, with a fairly long form. Then, the rheme's position is in the complement. The essence of Table 3 above is an explanation of the word "sad" (al-huznu). It is sad because of missing the opportunity to obey Allah SWT, but there was no effort to get up to do it. Then what is the new information (the rheme) in Table 3? The new information is that such sadness (theme) is a sign of deception (rheme). The justification that sadness without being accompanied by effort (a form of self-deception) is new information for the reader. From this example, the message organization structure can be seen in the Arabic and Indonesian clauses. In Table 3, there is a shifting translation, the word 'ala is translated as karena because in Bahasa Indonesia 'ala is a prepositional construction in Arabic, it is a letter of signification, structured on quiescence, it has no place in the analysis; it is also a letter of reduction, reducing the apparent and the personal nouns (El-Dahdah, 1993).

From the data above, we can see that the theme is focused on the word al-huznu. In this case, the word al huznu is classified in the form of ma'rifah. In Sufi terminology, humans can be divided into two groups, the ma'rifah (definite in Arabic) group and the nakirah (indeterminate in Arabic) group (Al-qusyairi, 2005). Ma'rifah position occupies the highest position (the position at the beginning of a clause), however, the position of the nakirah can also rise to the highest position. In this case, the position of the ma'rifah becomes the theme (with its locus at the starting point) of an utterance. From this, identifying the theme and rheme and theirpositions in the sentence, then Sufi healing can be done. One of the therapies being observe the form of the theme in Al-Hikam aphorisms. Textual meaning (as a part of metafunction) plays an important role in dividing a sentence into theme and rheme. By paying attention 
to the beginning of the utterance, the readers will select which one is the most important and which one is the most focused. Given this, the relationship between Al-Hikam aphorisms and Sufi healing can be found by using the metafunction analysis method.

\section{Clause as Exchange in Al-Hikam Aphorisms}

In the dimension of interpersonal function, clauses are seen as a source of meaning that relate to the functions of organizing the interaction process between writers/ speakers and readers/listeners. The clause is structured as interactive events (Halliday, 2004, p. 106).This section examines clauses as exchanges in terms of: (1) the clause system, (2) the structure of moods and residues, and (3) polarity and modality. The clause system explains that in writing, the author makes a choice, whether he will use an indicative clause or an imperative. Indicative is further divided into declarative or interrogative. Mood is a union of subject and finite. The residue is a residual structure other than "subject + finite." In the following sample data, the mood is "indicative + declarative."

$$
\text { شعاعُ البصيرة يشهدك قربه منكا }
$$

Syu' 'à'ul-bashīrah yusyhiduka qurbahu minka Sinar mata hati membuatmu menyaksikan kedekatan-Nya denganmu (Pustaka, 2016, p. 68).

The eyes of the heart make you witness His closeness to you

Table 4. The Structure of Mood and Residue

\begin{tabular}{|l|l|l|l|}
\hline & S & V & COMP \\
\hline A & $\begin{array}{l}\text { Syu'a' 'ul- } \\
\text { bashìrah }\end{array}$ & yusyhidu & $k a$ \\
\hline BI. & Sinar mata hati & $\begin{array}{l}\text { membuat menyak } \\
\text { sikan }\end{array}$ & mu \\
\hline & Subject & Finite/Predicator & \\
\hline & MOOD & RESIDUE & \\
\hline
\end{tabular}

Table 4 shows the SVCOMP as "Subject + Finite + Predicator" in examining clauses in an exchange of meaning. The subject in the clause is a noun in the form of the phrase "light of the heart." Meanwhile, the predicator is occupied by the verb yusyhidu, which is a verb that expresses something about the subject. The finite in the data above shows the tense in Arabic that is, the present tense. Between the subject and the finite in the data above there is agreement. Based on the second metafunction study, we can conclude that there is a relationship between a devotee and god. Mood is both subject and finite. Mood in this case can be the subject $(f \bar{a} ' i l)$. The $f \bar{a}$ ' $i l$ based on sufism terminology is al-Haqq (Allah SWT) (Al-qusyairi, 2005). The al-fäil occupies a high position, namely rafa' (regularity), it is a grammatical situation that requires vocalization of the word ending by means of vowel $/ \mathrm{u} /$ or any other sign of declension able to replace it (ElDahdah, 1993). Syu 'à 'ul-bashīrah occupies a high and noble position (it appears first in the clause). On the other hand, the ma'ful bih (Direct Patient in Arabic) is read in lower and softer voice than the subject, namely nashab. From the data in Table 4 above, the object is in the form of dhamir / ka/ (Personal pronounoun in Arabic ). In this case, $f \bar{a}$ ' $i l$ is Allah SWT and maf' $\bar{u} l$ bih (object) is the living being (makhluq). Interpersonal meaning teaches humans that there is a relationship between God and humans. In this type of analysis, Sufi healing can be seen from the perspective of personal meaning. Personal meaning seeks to investigate the relationship between God and humans.

\section{Clause as Representation in Al-Hikam Aphorisms}

In the dimension of ideational meaning, clauses are examined as sources of meaning representing experiences. Ideational meaning can be divided into experiential meaning and logical meaning. Ideational meaning related to experiential meaning is associated with a type of process known as transitivity. The process is expressed by a group of verbs, namely: (1) material processes, (2) mental processes, (3) relational processes, (4) verbal processes, (5) behavioral processes, and (6) existential processes.

$$
\text { شعاعُ البصبرة يشهدك قربه منك }
$$

\section{Syu 'à'ul-bashīrah yusyhiduka qurbahu minka}

Sinar mata hati membuatmu menyaksikan kedekatan-Nya denganmu (Pustaka, 2016, p. 68). The eyes of the heart make you witness His closeness to you

The phrase Syu'ā'ul-bashīrah is translated into Bahasa Indonesia as Sinar mata hati (The eyes of the heart) using a "literal technique," because this technique tries to translate a word or phrase word by word or word for word (Hartono, 2020, p. 18). Based 
Table 5. Structure of Theme and Rheme, Structure of Moods and Residues, and Structure of Mental Processes in SVCOMP

\begin{tabular}{|l|l|l|l|l|}
\hline S & V & COMP & minka \\
\hline Syu'a' 'ul-bashirah & yusyhidu & $k a$ & qurbahu & denganmu \\
\hline Sinar mata hati & membuat menyaksikan & $\mathrm{mu}$ & kedekatan-Nya & Circumstance \\
\hline Participant & Mental Process & Participant 1 & Participant 2 & \\
\hline THEME & RHEME & & \\
\hline MOOD & RESIDUE & & \\
\hline
\end{tabular}

on the last metafunction (ideational meaning), it can be seen that one form of Sufi healing can be elaborated by examining an experience. The experience of a Sufi can be seen in terms of his or her relationship with Allah SWT. These experiences can be grouped as material processes, mental processes, relational processes, verbal processes, behavioral processes, and existential processes. All of these processes can be used as a basis for Sufi healing, by observing the relationship between humans and God.

\section{Sufii Healing and The Transformational Meaning in Al-Hikam Aphorisms}

The fundamental basis for the study of Sufism is the Al-Hikam book of aphorisms. This book contains moral education and a guide for a Muslim devotee's efforts in pursuing a spiritual path. As a consequence, many use the book of Al-Hikam as their starting point for a spiritual revolution (Pustaka, 2016). The book of Al-Hikam aphorisms has a fairly high aesthetic level. The form of aesthetic language and its dense meaning presentsvarious kinds of problems in translation, such as how a translator makes decisions in translating aphorism. Translation studies in this case can be linked to Paul Ricoeur's hermeneutic model (Ricoeur, 2006). Translation is at the centre of Paul Ricoeur's philosophy. In terms of translation, there are two paradigms discussed by Ricoeur. First, the linguistic paradigm which describes how words relate to meanings in language or between languages. The analysis of meaning in this Al-Hikam aphorism study is very dominant with the discussion of heart (qalbun) and Sufism. Second, the ontological paradigm which describes how translation occurs between one human being and another. The operation of this paradigm can be seen in previous studies related to clause as representation in Al-Hikam aphorisms. One of Ricoeur's contributions to translation studies is to integrate hermeneutic elements. An important point that needs to be underlined is the fact that several major translations of biblical and classical texts play quite an important role in the development of national and cultural identities.
Sufi healing, related to Al-Hikam aphorisms is arguably closer to zikir (religious chanting to praise Allah). In Ricoeur's translation analysis model, translation can be viewed as comprising three important stages namely: (1) the wager, (2) the verification, and (3) the transformation. The three-stage model (wager, verification, and transformation) are at the core of Ricœur's infinite hermeneutics in translation. The first stage involves a wager that there is a symbolic meaning which differs from the normal or dictionary meaningfor example the word syu'ā'un (شعاع البصيرة) can be interpreted as: beam light, or streak while the word bashirah (بصيرة) can be interpreted as: brain, intellect, intelligence, mind, reason, sense, understanding, or wit. At the stage of verification, the newly interpreted and verified meaning can be realized, transforming the sense contained indictionary records, texts, and previous interpretations. In this case, Al-Hikam aphorisms book is not only a standalone linguistic unit arrangement, but it also has been transformed (second stage), realized in the study of Sufi healing namely therapy related to heart disease that the light of the heart (syua'ul bashirah) becomes the starting point in the utterance (theme). In this case, the theme becomes the main factor in Sufi healing. Studies related to the verification stage of the Rociouer model can be viewed from three kinds of metafunctions. The last stage is transformation, which can be applied to the Al-Hikam aphorisms and its relation to Sufi healing. As a part of Sufi healing, Al-Hikam aphorisms are positioned as a symbol.

An analysis of the symbols in Al-Hikam aphorisms, which are manifested in its words and phrases, leads to finding meaningful contents that allow for multiple interpretations. This is consistent with what Ricoeur's model where a symbol is any double-meaning expression defined by a semantic structure in which the first-order meaning designates a second-order meaning that is attainable only through the first-order meaning. Word symbols and phrase symbols in the Al-Hikam aphorisms basically show the form of a devotee's love for Allah SWT. In Ricoeur's view, translation can be understood in both a specific sense and general sense. In a specific sense, what 
we have understood in translation so far is translating the meaning of one language into another. This is similar to the experience of the general public who understands the text of Al-Hikam aphorisms through the translated text. Meanwhile, in the study of general sense, translating is understood not only as a process of translating from the internal side (inner to outer, private to public, unconscious to conscious), but also more explicitly from one person to another. This latter understanding has been applied in this research, that the text of Al-Hikam is positioned not only as a religious text, but based on the study of metafunction and infinite hermeneutics in translation, $\mathrm{Al}$ Hikam aphorismss can be used as a basis for studies in Sufi healing. In addition, Ricoeur also emphasizes that translation is a replica of the original form (the illusion of a total translation which would provide a perfect replica of the original). According to Ricoeur, the awakening of thought begins with symbols. Meaning is born from symbols. The meaning that is born from this symbol is a form of logical thinking. Sufi text is a text that is rich in symbols, especially symbols of the devotee's love for God. The translation product will provide direction for the transcendental experience which manifests in units of language in the book of Al-Hikam aphorisms. Ricoeur emphasizes that the object of consciousness is an entity that can be repeated and can be signified in various ways. In the end, the sign will lead to the transcendental experience felt by the author. In this case, intentionality and meaning are things that are coextensive. What is experienced is always correlated with how it is experienced by someone (Kaplan, 2003, p. 18). Based on Ricoeur's hermeneutic theory, it can be concluded that the symbols conveyed by the Sufis in the Al-Hikam aphorisms in essence, show the form of a devotees' love for Allah SWT. Additionally, the Al-Hikam aphorisms have a strong relationship with Sufi healing. This finding is is shown in the distribution of the types of themes contained in the Al-Hikam aphorisms. The data used in this study amounted to 435 clauses containing thematic structure in $100 \mathrm{Al}$-Hikam aphorisms, which have been translated from Arabic to Indonesian and English.

The high percentage of topical unmarked themes (simple theme, theme was identified for each clause) shows that textually, the distribution of information on Arabic-English-Indonesian translated aphorisms organized in a coherent and systematic manner through placing the subject in front of the clause as a tool to emphasize the main issues discussed in it. Based on this positioning, dominant subjects are Allah SWT, the heart (qalbun), the the relationship between Allah SWT and humans. This shows that the Al-Hikam aphorisms have a strong relationship with Sufi healing, a method that elaborates on healing the human heart (qalbun) by improving a devotee's moral-ethical behavior towards God. Interpersonal theme data have the lowest frequency, especially in the target languages (English and Indonesian). This indicates that the translated texts (English and Indonesian) have a limited relationship and interpersonal interaction when compared to the source text, the Al-Hikam aphorisms in Arabic. In addition, the low number of interpersonal themes in the target language (English and Indonesian) is caused by the application of translation techniques. This research finds that there is a need to further develop the understanding of Sufi healing in Indonesia. Sufi healing is one solution in the treatment of the heart (qalbun). Sufi healing also helps devotee's to become closer to Allah SWT and find inner peace.

\section{CONCLUSION}

Based on the results of the data analysis, we can conclude that the clause structure in Arabic can be divided into three main patterns, namely (1) SVCOMP/entity-oriented, (2) VSCOMP/event-oriented, and (3) SCOMP/verbless sentence structure. Several translation techniques have been applied in translating Al-Hikam aphorisms from Arabic into Indonesian. The three types of clauses occupy three dimensions of meaning in the systemic linguistic paradigm: (1) the clause as message, (2) the clause as exchange, and (3) the clause as representation. Sufi healing in the book of Al-Hikam aphorisms can be investigated using Paul Ricoeur's analysis model. This three-stage model (wager, verification, and transformation) is at the core of his infinite hermeneutics in translation. In this study, the position of wager was viewed from the lexical meaning of the Al-Hikam aphorisms (the meanings of the words used in the Al-Hikam aphorisms). The Ricoeur stage of verification is related to metafunction, such as textual meaning, interpersonal meaning, and ideational meaning. The transformation stage in the model, as shown in this study, can be applied to the study of Al-Hikam aphorisms as a basis for understanding Sufi healing.

\section{ACKNOWLEDGEMENT}

This research is part of a doctoral dissertation supervised by Mangatur Nababan, Riyadi Santosa, and Mohammad Masrukhi at Sebelas Maret University. However, the research findings presented in this paper are the authors alone. This research was funded by PTNBH Sebelas Maret University's RKAT for Fiscal Year 2021 through a doctoral dissertation research scheme (pdd-uns) with 
Contract Number: 260/UN27.22/HK.07.00/2021.

\section{REFERENCES}

Abdul-Raof, H. (2007). Subject, Theme and Agent in Modern Standard Arabic. Routledge Taylor \& Francis Group.

Abdullah, M. (2018). Jejak Islamisasi Jawa Oleh KH Soleh Darat ( Studi Kasus Naskah Kitab Syarah Al-Hikam ). Jurnal NUSA: Jurnal Ilmu Bahasa Dan Sastra, 13(3), 418-430. https://ejournal.undip.ac.id/index. $\mathrm{php} /$ nusa/article/view/20581/13968

Aini, V. N., Fitriati, S. W., \& Bharati, D. A. L. (2020). The shift of the thematic structure in English-Indonesian translation of Flipped subtitles. English Education Journal, 10(2), 190-200.

Al-Chishtiyya, H. abu-A. M. (1991). The Book of Sufi Healing. Inner Traditions International.

Al-qusyairi, I. (2005). Nahwul-Qulub. Darul Kutub alIlmiyah.

Almanna, A. (2016). The Routledge Course in Translation Annotation. Routledge.

Anis, M. Y. (2018). Kesepadanan Tekstual dan Ideologi Penerjemahan Arab-Jawa dalam Kitab Sharh alHikam. TEOSOFI: Jurnal Tasawuf Dan Pemikiran Islam, 8(2), 302-324. http://jurnalfuf.uinsby.ac.id/ index.php/teosofi/article/view/189

Aryati, A. (2017). PEMIKIRAN TASAWUF SYEIKH IBN 'ATOILLAH AS-SAKANDARI DALAM KITAB AL HIKAM (Kajian Tentang Rekonstruksi Dan Kontribusi Nilai-Nilai Tasawuf Dalam Pendidikan Islam). MANHAJ: JURNAL PENELITIAN DAN PENGABDIAN MASYARAKAT, 6(1), 1-7. https:// ejournal.iainbengkulu.ac.id/index.php/manhaj/ article/view/746

As-Sakandariy, I. A. (2008). Al-Hikam al-'Athà'iyyah Lisy-Syaikh Tājid-Dīn Aḥmad Ibnu 'Athā'illāhi AsSakandairy. Dārus-Salāmi.

Baalbaki, R. (2009). Al-Mawrid Arabic English Dictionary. Dar el-Ilm Lil Malayin.

Baalbaki, R. M. (1990). Dictionary of Linguistics Terms. Dar el-Ilm Lil-Malayin.

Baker, M. (2018). In other words : a coursebook on translation. Routledge.

Damayanti, D. A. (2014). TINDAK TUTUR KIAI MENGENAI SYARAH ( PENJELASAN) KITAB AL-HIKAM DAN TAFSIR Al QUR'AN DALAM PENGAJIAN. 14(1), 58-70. https://ejournal.upi.edu/ index.php/BS_JPBSP/article/view/710/510

Dewi, S. N., Saragih, A., \& Pulungan, A. H. (2020). THE REALIZATION THEME AND RHEME IN MANDAILING SONG TEXTS. LINGUISTIK: Jurnal Bahasa \& Sastra, 5(1, Januari-Juni), 71-79. http://jurnal.um-tapsel.ac.id/index.php/Linguistik/ article/view/1618

El-Dahdah, A. (1993). A Dictionary of Arabic Grammatical Nomenclature: Arabic-English. Librairie du Liban Publishers.

Ethelb, H. (2019). Thematic Analysis in Translating English and Arabic Scientific Texts. Advances in Language and Literary Studies, 10(4), 88-94. https://doi. org/10.7575/aiac.alls.v.10n.4p.88

Halliday, M. A. K. (2004). An Introduction to Functional Grammar: Third Edition. Hodder Arnold.

Hartono, R. (2020). Translation Techniques \& Methods. LPPM UNNES Press.

Holes, C. (1995). Modern Arabic Structure, Functions and Varieties. Longman.

Kadhim, K., \& Al-shaibani, G. K. S. (2013). Analysis of Thematic Structure in English-Arabic News Texts. Topics in LInguistics, December(12), 33-45.

Kaplan, D. M. (2003). Ricoeur's Critical Theory. State University of New York Press.

Karini, Z. (2016). ANALISIS PENERJEMAHAN TEMA TOPIKAL PADA BUKU CERITA ANAK BILINGUAL 'SANGKURIANG.' Jurnal Kependidikan, IV(2), 189-201.

Kharmandar, M. A. (2015). Ricœur's Extended Hermeneutic Translation Theory: Metaphysics, Narrative, Ethics, Politics. Études Ricoeuriennes / Ricoeur Studies, 6(1), 73-93. https://doi.org/10.5195/errs.2015.281

Kridalaksana, H. (2009). Kamus Linguistik Edisi Keempat. PT Gramedia Pustaka Utama.

Miles, M. B., \& Huberman, ;A Michael. (1992). An Expanded Sourcebook Qualitative Data Analysis. In Archives of Gynecology and Obstetrics (Vol. 251, Issue 2). Sage Publication.

Nugraha, A. D. S. (2017). STRUKTUR TEMA-REMA DALAM TEKS ABSTRAK BERBAHASA INDONESIA. Sirok Bastra Jurnal Kebahasaan Dan Kesastraan, 5(1, Juni), 15-28. http://garuda. ristekbrin.go.id/documents?select=title\&q=konstru $\mathrm{ksi}+$ tema+rema\&pub=

Potter, L. (2016). Ideological representations and ThemeRheme analysis in English and Arabic news reports: a systemic functional approach. https://doi. org/10.1186/s40554-016-0028-y

Pustaka, T. W. (2016). Al-Hikam: Kitab Rujukan Ilmu Tasawuf Edisi Lengkap 3 Bahasa. Wali Pustaka.

Rahem, Z. (2017). AJARAN PENDIDIKAN ANTI KORUPSI IBNU ATHAILLAH ( Menggali Nilai Pendidikan Moral-Spritual dari Sebagian Untaian Hikmah Kitab Al-Hikam ). FIKROTUNA: Jurnal Pendidikan Dan Manajemen Islam, 6(2), 586-599. https://doi.org/https://doi.org/10.32806/jf.v6i2.3115

Ricoeur, P. (2006). On Translation. Routledge Taylor \& Francis Group.

Rini, S. (2015). CONTRASTIVE ANALYSIS ON 
THE THEME/RHEME STRUCTURE ON HEADLINES OF THE JAKARTA POST AND MEDIA INDONESIA Setia Rini State University of Semarang. Leksika: Jurnal Bahasa, Sastra Dan Pengajarannya, 9(2), 8-14. http://jurnalnasional. ump.ac.id/index.php/LEKSIKA/article/view/11

Sakhok, J., Munandar, S. A., \& Ladzidzah, I. (2019). Tasawuf dan Budaya Populer: Studi atas Pengajian Online Kitab Al-Hikam di Facebook oleh Ulil Abshar Abdalla. Esoterik: Jurnal Akhlak Dan Tasawuf, 05(02), 387-412. https://doi.org/10.21043/esoterik. v5i2.6446

Stella, G., \& Gunawan, S. (2017). an Analysis of Theme and Rheme Used in the Five-Star Hotels' Web Sites in Surabaya. Kata Kita: Journal of Language, LIterature, and Teaching, 5(1), 54-59. https://doi. org/10.9744/katakita.5.1.54-59

Sujono, A., Mangatur, N., Djatmika, \& Wiratno, T. (2016). A TRANSLASTION ANALYSIS OF THE MULTIPLE THEMES SHIFTS IN RUMI : Proceedings of The Third International Seminar of PRASASTI, 92-98. https://jurnal.uns.ac.id/prosidingprasasti/article/ view/1450
Sukesti, R. (2011). Tema - Rema dalam Bahasa Jawa Ngoko dialek Banyumas: Kajian penataan organisasi informasi. Jurnal Humaniora, 23(2), 219 - 228.

Suparno. (1993). Konstruksi tema rema dalam Bahasa Indonesia lisan tidak resmi masyarakat Kotamadya Malang. Pusat Pembinaan dan Pengembangan Bahasa.

Syukur, A. (2011). Sufi Healing: Terapi Dalam Literatur Tasawuf. Walisongo Press.

Wahyu, A., Sinulingga, K., \& Hasibuan, A. (2019). THE ANALYSIS OF THEME-RHEME ORGANIZATION ON JOKOWI WIDODO' $\mathrm{S}$ SPEECH. Jurnal Pendidikan Bahasa Indonesia Dan Sastra (Pendistra), 2(2), 65-70. http://garuda. ristekbrin.go.id/documents?select=title\&q=konstru $\mathrm{ksi}+$ tema + rema\&pub $=$

Wang, F. (2014). The application of thematic theory in translation. Theory and Practice in Language Studies, 4(4), 778-785. https://doi.org/10.4304/tpls.4.4.778785

Wiratno, T. (2018). Pengantar Ringkas Linguistik Sistemik Fungsional. Pustaka Pelajar. 